\title{
Two new species of Synsphyronus (Pseudoscorpiones: Garypidae) from southern Western Australian granite landforms
}

\author{
Mark S. Harvey \\ Department of Terrestrial Zoology, Western Australian Museum, Locked Bag 49, Welshpool DC, \\ Western Australia 6986, Australia. Email: mark.harvey@museum.wa.gov.au [Division of Invertebrate \\ Zoology, American Museum of Natural History, New York; California Academy of Sciences, San \\ Francisco; School of Animal Biology, University of Western Australia, Crawley, Western Australia \\ 6009, Australia].
}

\begin{abstract}
Two new species of Synsphyronus, S. francesae and S. ellenae, are described from southern Western Australia. These species occur on granite outcrops where they congregate under exfoliating pieces of granite. Synsphyronus francesae occurs near the south coast of Western Australia, while S. ellenae occurs in the central wheatbelt region. Synsphyronus ellenae is the first species of the genus with an adult trichobothrial pattern of six trichobothria on the fixed finger and two on the moveable finger (6/2), although some variation was observed with five or seven trichobothria occasionally present. All other species of Synsphyronus have patterns of 8/3, 8/2,8/1, 7/2 or $7 / 1$. The only other species of Garypidae with a 6/2 pattern is Meiogarypus mirus Beier from Namibia, and the only species with lower trichobothrial numbers are Elattogarypus cruciatus Beier from South Africa, E. somalicus Mahnert from Somalia, E. cicatrosus Mahnert from the Yemeni island of Socotra, and Eremogarypus eximius Beier from Namibia, each with a 5/1 pattern. The conservation status of these species is examined.
\end{abstract}

KEYWORDS: inselbergs, monadnocks, taxonomy, morphology, Arachnida, conservation, short-range endemics.

\section{INTRODUCTION}

Granite domes - also known as inselbergs or monadnocks - are a conspicuous geomorphological feature of many Australian landscapes and can comprise large monoliths rising hundreds of metres above the surrounding landscape, to low platforms barely higher than their surroundings (Bayly 1999; Withers 2001). The fauna associated with Australian granite outcrops is known to be diverse and comprises aquatic elements dependent upon rock pools and seeps, or terrestrial species living under loose pieces of exfoliating granite or on the soil aprons adjacent to the rock (Main 1998a; Withers and Edward 1998; Bayly 1999; Main 2001). Arachnids comprise a significant component of the terrestrial fauna of granite domes and many different groups were documented by Main (1998a, 2001). Although several different pseudoscorpion taxa are known to be found on or adjacent to granite rocks, members of the genus Synsphyronus Chamberlin, 1930 are the most abundant and are frequently encountered.

Species of Synsphyronus are found in most regions of Australia and in New Zealand, with 26 species currently named from Australia and two from New Zealand (Harvey 1987). The discovery of an additional species, which is currently unnamed, from New Caledonia (Harvey 1996a) further extends the distribution of the genus within the Australasian region. Numerous new species of the genus have since been discovered in Australia (Harvey, unpublished data), many of which emanate from Western Australia. This paper reports the discovery of two previously unnamed species from southwestern Australia. One of these species is remarkable for the reduced number of trichobothria on the fixed chelal finger. Although trichobothrial numbers are generally quite stable within each species of Synsphyronus, there is considerable variation between species, with the fixed finger of adults bearing seven or eight trichobothria, and the moveable finger bearing one, two or three trichobothria. The most common pattern is $8 / 3$, with $8 / 2,8 / 1,7 / 2$ and $7 / 1$ being variously represented in other species. Descriptions of these two new species are presented here to provide additional knowledge on the indigenous fauna of southwestern Australia. 


\section{MATERIAL AND METHODS}

The material utilized in the present study is lodged in the Western Australian Museum, Perth (WAM), with paratypes of one species lodged in the Australian Museum, Sydney (AM), American Museum of Natural History, New York (AMNH), Australian National Insect Collection, Canberra (ANIC), California Academy of Sciences, San Francisco (CAS), Museum of Comparative Zoology, Harvard University, Cambridge (MCZ), Muséum d'Histoire Naturelle, Geneva (MHNG), Muséum National d'Histoire Naturelle, Paris (MNHN), Museum Victoria, Melbourne (NMV), Queensland Museum, Brisbane (QM) and South Australian Museum, Adelaide (SAM).

Terminology and mensuration largely follow Chamberlin (1931), with the exception of the nomenclature of the pedipalps and legs, and with some minor modifications to the terminology of the trichobothria (Harvey 1992) and chelicera (Judson 2007).

The specimens were examined in temporary slide mounts by immersing the specimen in $75 \%$ lactic acid or in oil of cloves at room temperature for several days, and mounting them on microscope slides with 10 or $12 \mathrm{~mm}$ coverslips supported by small sections of $0.25 \mathrm{~mm}$ or $0.50 \mathrm{~mm}$ diameter nylon fishing line. They were examined with a Leica DM2500 compound microscope and illustrated with the aid of a drawing tube. Measurements were taken at the highest possible magnification using an ocular graticule. After study each specimen was returned to $75 \%$ ethanol with the dissected portions placed in $12 \times 3 \mathrm{~mm}$ glass genitalia microvials (BioQuip Products, Inc.).

\section{Family Garypidae Simon, 1879}

\section{Genus Synsphyronus Chamberlin, 1930}

Synsphyronus Chamberlin, 1930: 616.

Maorigarypus Chamberlin, 1930: 617 (synonymised by Chamberlin 1943: 488).

Idiogarypus Chamberlin, 1943: 499 (synonymised by Morris 1948: 37).

\section{TYPE SPECIES}

Synsphyronus: Synsphyronus paradoxus Chamberlin, 1930, by original designation.

Maorigarypus: Maorigarypus melanochelatus Chamberlin, 1930, by original designation.

Idiogarypus: Garypus hansenii With, 1908, by original designation.

\section{DIAGNOSIS}

Species of Synsphyronus resemble those of Paragarypus Vachon, 1937, Thaumastogarypus Beier,

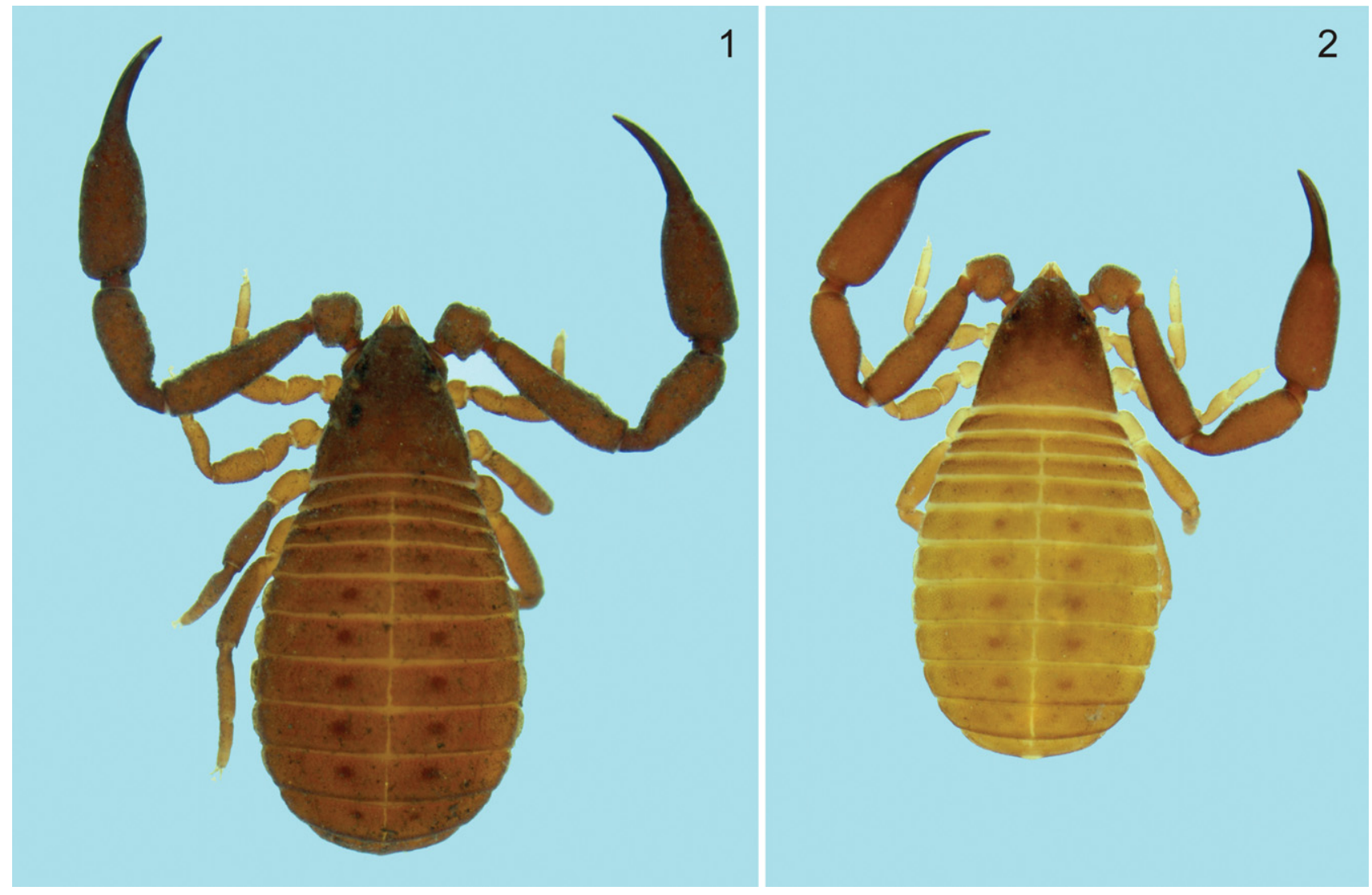

FIGURES 1-2 1, Synsphyronus francesae sp. nov., paratype male (WAM T64692); 2, S. ellenae, paratype male (WAM T54168). To same scale. 


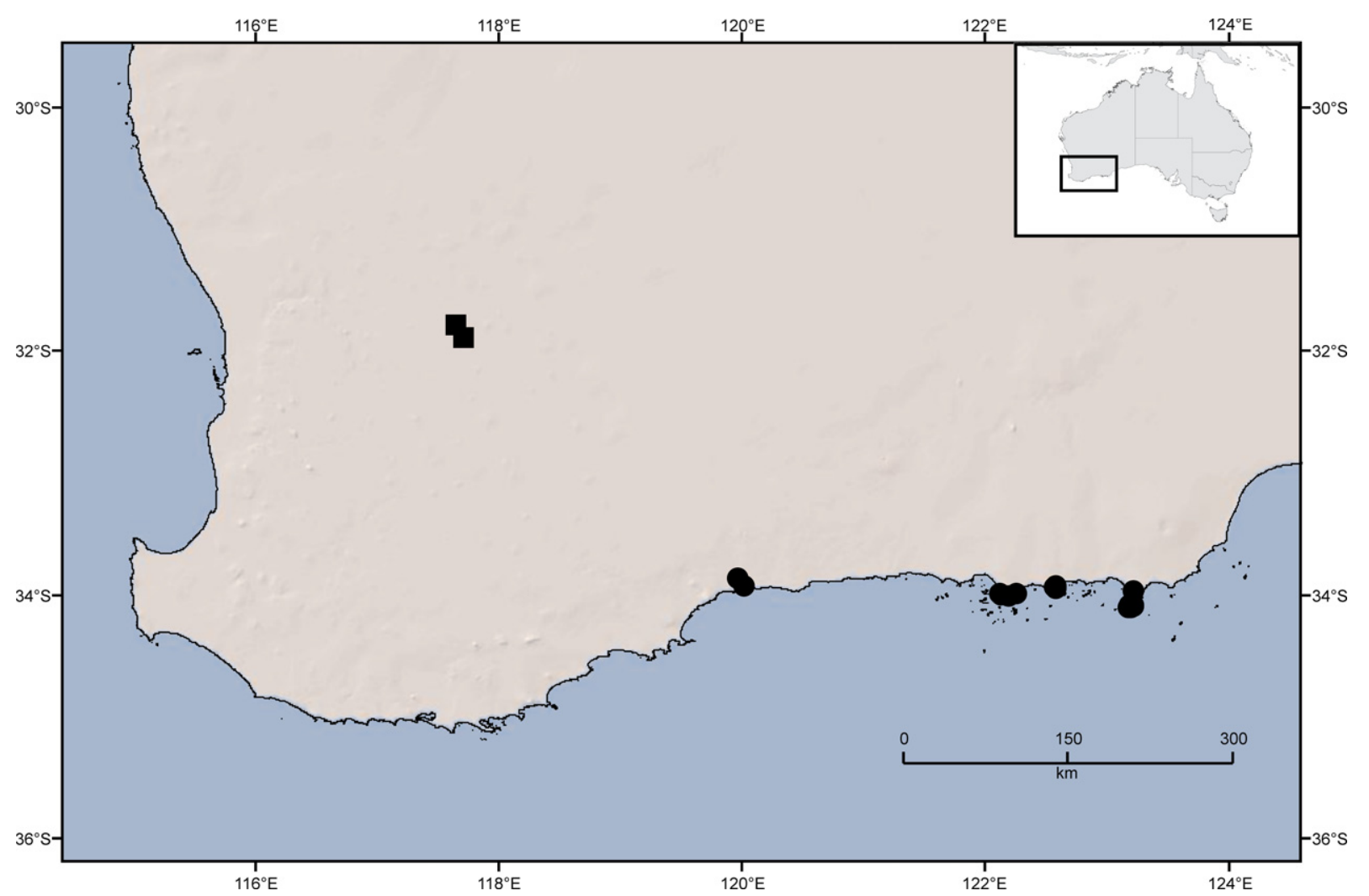

FIGURE 3 Map of southwestern Australia showing known distributions of Synsphyronus francesae sp. nov. ( $)$ and S. ellenae sp. nov.

1947 and Ammogarypus Beier, 1962 in the possession of clavate, quadricarinate setae that are usually directed at right angles to the tegument. The three African genera differ from Synsphyronus in the relative positions of trichobothria $i b$ and ist: trichobothrium $i b$ is situated posterodorsally to ist in Synsphyronus, but is situated posteroventrally in Paragarypus, Thaumastogarypus and Ammogarypus (e.g. Vachon 1937b; Beier 1947, 1962, 1964; Mahnert 1982; M.S. Harvey 1987, personal observations).

\section{Synsphyronus francesae sp. nov.}

Figures 1, 3-12

\section{MATERIAL EXAMINED}

\section{Holotype}

Australia: Western Australia: $\hat{\jmath}$, Cape Le Grand National Park, Le Grand Beach, 3358'52"S, $122^{\circ} 07^{\prime} 16^{\prime} \mathrm{E}, 15$ January 2004, under granite rocks, M.S. Harvey, M.E. Blosfelds, F. Harvey and E. Harvey (WAM T85198).

\section{Paratypes}

Australia: Western Australia: 20 , collected with holotype (WAM T64692); 8 \%, collected with holotype (WAM T85202); 1 q with brood-sac, collected with holotype (WAM T64691); 1 tritonymph, collected with holotype (WAM T85199); 8 tritonymphs, collected with holotype (WAM T85200); 1 deutonymph, collected with holotype (WAM T85201); $1 \hat{\jmath}, 1$, collected with holotype (AM); 1 O, 1 q, collected with holotype (ANIC); $1 \hat{\jmath}, 1$, collected with holotype (MCZ); $1 \hat{\sigma}, 1$ q, 1 tritonymph, collected with holotype (MHNG); 1 స, 1 , 1 tritonymph, collected with holotype (MNHN); 1 ๙ , 1 q, collected with holotype (NMV); 1 ô, 1 , collected with holotype (QM); 1 ô, 1 \%, collected with holotype (SAM).

\section{OTHER MATERIAL EXAMINED}

Australia: Western Australia: 15 त, 12 †, 3 tritonymphs, 1 deutonymph, 1 protonymph, Cape Arid National Park, Mt Arid south side near summit, $33^{\circ} 57^{\prime} 45^{\prime \prime S}, 123^{\circ} 13^{\prime} 01^{\prime \prime E}$, 5 June 2007, under rocks, M.L. Moir, M.C. Leng (WAM T80666); 5 ô, 4 o, 4 tritonymphs, Cape Le Grand National Park, outcrop above Rossiter Bay, 33 $58^{\prime} 48^{\prime \prime S}, 122^{\circ} 15^{\prime} 41^{\prime \prime E}, 4$ June 2007, under granite rocks, M.L. Moir, M.C. Leng (WAM T80729); 26 §ิ, 15 ㅇ, 10 tritonymphs, Cape Le Grand National Park, Mt Le Grand summit, 3359'41"S, $122^{\circ} 07^{\prime} 48^{\prime \prime E}, 4$ June 2007, under granite rocks, M.L. Moir, M.C. Leng (WAM T80732); 5 ㅇ (some with brood-sacs), Cape Le Grand National Park, off Thistle Beach, 3400'16"S, 122 11'30"E, 17 November 2006, under granite rock, M.L. Moir (WAM T78833); 1 के, 7 9, 4 tritonymphs, Cape Le Grand National Park, off Thistle Beach, 3400'19"S, 122 $2^{\circ} 11^{\prime} 47^{\prime \prime E}, 17$ November 2006, under granite rock, M.L. Moir (WAM T78832); 2 ô, 1 ㅇ, Middle Island, Recherche Archipelago, 3406'S, $123^{\circ} 11^{\prime} \mathrm{E}, 8-9$ April 1989, A.F. Longbottom (WAM T56031); 2 今, 1 ᄋ, Middle Island, Recherche Archipelago, 

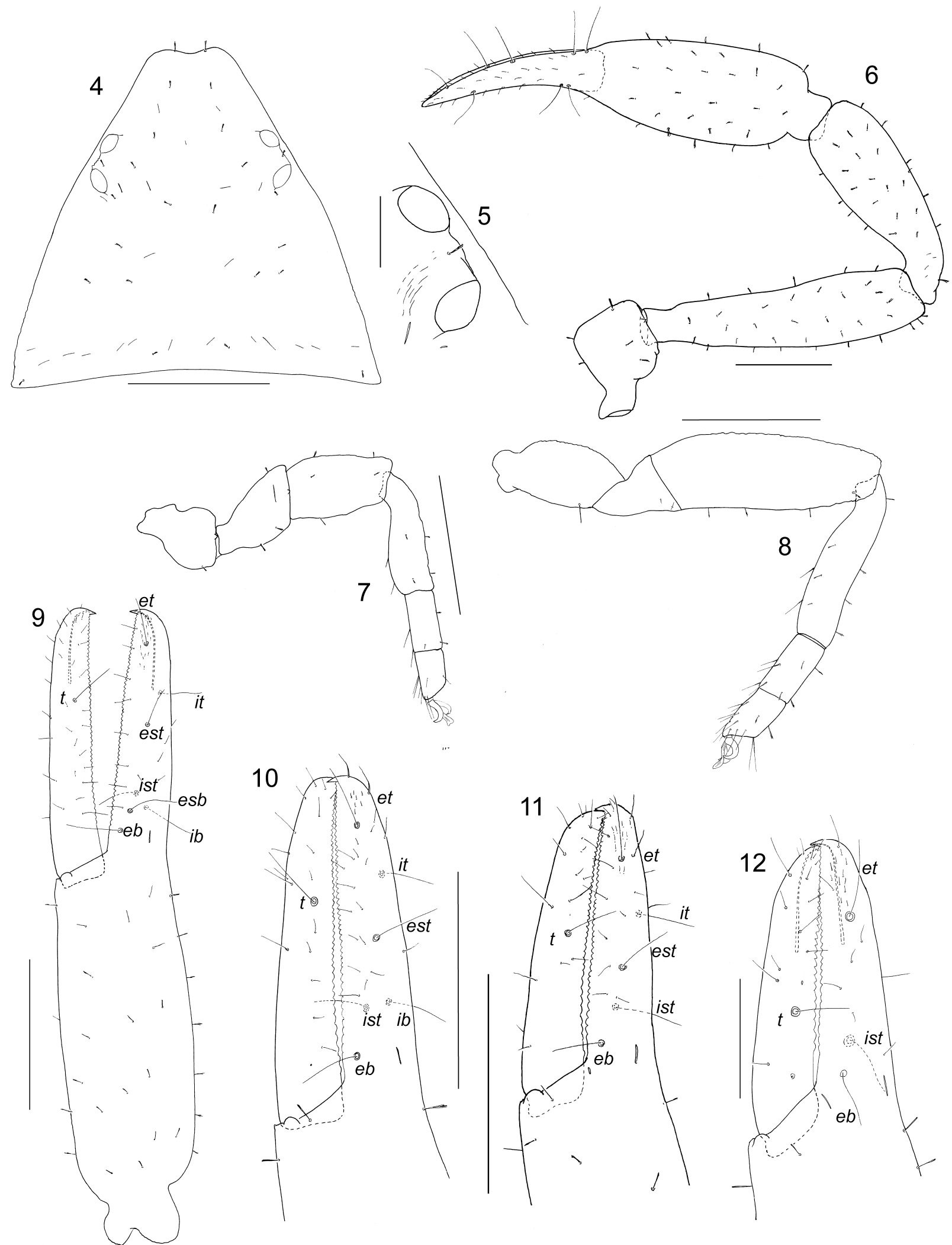

FIGURES 4-12 Synsphyronus francesae sp. nov., holotype male (WAM T85198), unless stated otherwise: 4, carapace; 5, right eye group; 6, right pedipalp, dorsal view; 7, left leg I; 8, left leg IV; 9, left chela, lateral view; 10, left chelal fingers, lateral view, paratype tritonymph (WAM T85199); 11, left chelal fingers, lateral view, paratype deutonymph (WAM T85201); 12, left chelal fingers, lateral view, paratype protonymph (WAM T80666). Scale lines = $0.5 \mathrm{~mm}$ (Figures 4, 6-11), $0.2 \mathrm{~mm}$ (Figure 12), 0.1 $\mathrm{mm}$ (Figure 5). 
$34^{\circ} 06^{\prime} \mathrm{S}, 123^{\circ} 11^{\prime} \mathrm{E}$, November 1974, H. Bakke (WAM T56029); 6 o, 1 †, Middle Island, Recherche Archipelago, $34^{\circ} 06^{\prime} \mathrm{S}, 123^{\circ} 11^{\prime} \mathrm{E}, 8^{-}-9$ April 1989 , under granite slabs, A.F. Longbottom (WAM T56030); 2 ô, Recherche Archipelago, Middle Island, $34^{\circ} 05^{\prime} 34^{\prime \prime} \mathrm{S}, 123^{\circ} 11^{\prime} 45^{\prime \prime} \mathrm{E}$, 22 October 2008, under granite rocks, M.S. Harvey et al. (WAM T95642); 1 §ิ, 1 ㅇ, 1 deutonymph, Recherche Archipelago, Middle Island, Flinders Peak, $34^{\circ} 05^{\prime} 41^{\prime \prime S}$, $123^{\circ} 10^{\prime} 23 " \mathrm{E}, 24$ October 2008, under granite rocks, M.S.

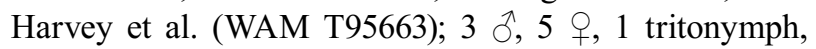
1 deutonymph, 1 protonymph, Recherche Archipelago, Middle Island, $34^{\circ} 05^{\prime} 36^{\prime \prime S}, 123^{\circ} 11^{\prime} 45^{\prime \prime} \mathrm{E}, 22$ October 2008, under granite rocks, M.S. Harvey, et al. (WAM T95680); 1 त, 2 ㅇ, Recherche Archipelago, Middle Island, $34^{\circ} 04^{\prime} 57^{\prime \prime S}, 123^{\circ} 12^{\prime} 54^{\prime \prime E}, 23$ October 2008, under granite rocks, M.S. Harvey et al. (WAM T95690); 4 ठ, 2 +1 tritonymph, 1 deutonymph, Recherche Archipelago, Middle Island, $34^{\circ} 05^{\prime} 03^{\prime \prime} \mathrm{S}, 123^{\circ} 12^{\prime} 50^{\prime \prime} \mathrm{E}, 23$ October 2008, under granite rocks, M.S. Harvey et al. (WAM T95696); 5 ते, 4 ㅇ, Recherche Archipelago, Middle Island, $34^{\circ} 05^{\prime} 12^{\prime \prime} \mathrm{S}, 123^{\circ} 12^{\prime} 44^{\prime \prime} \mathrm{E}, 23$ October 2008, under granite rocks, M.S. Harvey et al. (WAM T95698); 1

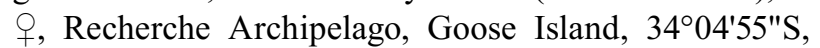
$123^{\circ} 11^{\prime} 00^{\prime \prime E}, 22$ October 2008, under granite rocks, M.S. Harvey et al. (WAM T95710); 1 ð, Fitzgerald River National Park, S. slopes of East Mt Barren, $33^{\circ} 55^{\prime} \mathrm{S}$, $120^{\circ} 01^{\prime} \mathrm{E}, 26$ May 1994, under rocks, M.S. Harvey, J.M. Waldock, G. Harold, N. Brown (WAM T56027); 1 , Fitzgerald River National Park, Eyre Range, rock outcrop, 3351'11"S, 11957'58"E, 30 May 2007, under rock, M.L. Moir, M.C. Leng (WAM T80793); 2 + , Duke of Orleans

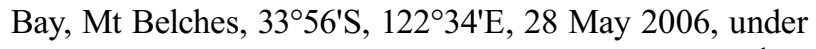
granite slab, A.F. Longbottom (WAM T76120); 4 O, 3 + , Little Wharton Bay, Duke of Orleans Bay, $33^{\circ} 55^{\prime} \mathrm{S}$, $122^{\circ} 35^{\prime} \mathrm{E}, 29$ December 1998, under granite slabs above bay, A.F. Longbottom (WAM T56028); 17 ภ, 7 क, 2 tritonymphs, 1 deutonymph, 1 protonymph, Duke of Orleans Bay, Mt Belches near summit, 3356'26"S, $122^{\circ} 34^{\prime} 31^{\prime \prime E}, 2$ June 2007, under granite rocks, M.L. Moir, A. Longbottom (WAM T80701); 1 ․ Duke of Orleans Bay, Mt Belches near summit, 3356'26"S, $122^{\circ} 34^{\prime} 31^{\prime \prime E}, 2$ June 2007, under granite rocks, M.L. Moir, A. Longbottom (WAM T95091).

\section{DIAGNOSIS}

Adults of Synsphyronus francesae possess separate metatarsi and tarsi (Figures 7, 8), and a trichobothrial pattern of seven trichobothria on the fixed chelal finger and one on the movable finger (Figure 9). It differs from the only other named species of the genus sharing these features, S. nullarborensis Beier, 1969, by its substantially larger size, e.g. chela (with pedicel) 1.95$2.17\left({ }^{\top}\right), 2.29-2.47$ (ㅇ) $\mathrm{mm}$ in length, compared with $1.385-1.71\left({ }^{\Uparrow}\right), 1.515-1.78 \mathrm{~mm}(+)$ in S. nullaborensis.

\section{DESCRIPTION}

\section{Adults}

Colour of sclerotized portions generally dark redbrown (Figure 1). Waxy epicuticle. Setae generally aligned perpendicularly from body, each seta quadricarinate. Most cuticular surfaces roughened, but not granulate.

Chelicera: with 5 setae on hand and 1 subdistal seta on movable finger, all setae acuminate; setae $s b s$ and $b s$ shorter than others; 2 dorsal lyrifissures and 1 ventral lyrifissure; galea of $\delta$ and $q$ unbranched; rallum of 3 blades, the most distal blade with several serrations on leading edge, other blades smooth; serrula exterior with $22($ ঐ), 23 (†) blades; lamina exterior present.

Pedipalp (Figure 6): trochanter 1.39 (đ)), 1.39 ()), femur 3.95-4.30 (đ), 4.05-4.40 (), patella 2.81-3.10 (đ), 2.88-3.17 (P), chela (with pedicel) 3.81-4.29 (ふ), 4.00-4.32 (†), chela (without pedicel) 3.69-4.00 (ふ), 3.83-4.17 (), hand 1.95-2.14 (ठ) , 2.07-2.23 () times longer than broad, movable finger 0.88-0.96 ( $\left.{ }^{\star}\right)$, $0.87-0.97$ (P) times longer than hand. Fixed chelal finger with 7 trichobothria, movable chelal finger with 1 trichobothrium (Figure 9): $i s b, s t, s b$ and $b$ absent; $e b$ and $e s b$ situated basally, est submedially, et subdistally, $i b$ and ist basally in diagonal row, and $i t$ subdistally, well posterior to $e t$; $t$ situated subdistally; patch of microsetae present on external margin of fixed chelal finger near et. Venom apparatus present in both chelal fingers, venom ducts long, terminating in nodus ramosus near est in fixed finger and near $t$ in movable finger. Chelal teeth retrorse and acute distally, becoming rounded basally; fixed finger with $53(\widehat{)}), 60$ () teeth; movable finger with $47\left({ }^{\Uparrow}\right), 52$ (ㅇ) teeth; accessory teeth absent.

Carapace (Figure 4): 0.87-0.94 (ठ), 0.84-0.93 () times longer than broad; anterior margin slightly indented medially; subtriangular; with 2 pairs of rounded corneate eyes (Figure 16) situated one-third carapace length from anterior margin; with c. $20(\hat{0}$, +) setae, including 2 near anterior margin and 4 near posterior margin; with numerous lyrifissures; without furrows.

Coxal region: manducatory process rounded, with 3 apical acuminate setae; medial maxillary lyrifissure situated submedially; chaetotaxy of coxae I-IV: $\widehat{O}, 3: 4$ : 5: 6; 우, 4: 5: 5: 8 .

Legs (Figures 7, 8): junction between femora and patellae I and II slightly oblique to long axis; junction between femora and patellae III and IV very angulate; femora III and IV much smaller than patellae III and IV; femur + patella of leg IV $3.93\left(\delta^{\Uparrow}\right), 4.03$ (ㅇ) times longer than broad; metatarsi and tarsi not fused and without tactile seta; subterminal tarsal setae arcuate and acute; arolium much longer than claws, not divided.

Abdomen: tergites II-X completely divided by median suture line (Figure 1); sternites V-X with medial suture line, sometimes incompletely divided. Tergal chaetotaxy: 0 4: 4: 4: 4: 6: 6: 8: 8: 8: 8: 4: 2; ㅇ $4: 4: 4: 6$ : 8: 8: 8: 8: 8: 8: 6: 2 , uniseriate; all setae quadricarinate. Sternal chaetotaxy: 0 8: (0) 6 [4+4] (0): (0) 6 (0): 6: 4: 5: 6: 6: 8: 4: 2; 우 6: (0) 8 (0): (0) 7 (0): 8: 10: 10: 10: 10: 6: 4: 2 ; uniseriate; all setae quadricarinate except for setae on sternites II-IV and medial setae on sternites 
V-IX, which are acuminate. Spiracles without helix. Anal plates (tergite XII and sternite XII) situated within sternite XI, surrounded by slightly raised rim. Pleural membrane wrinkled-plicate; without any setae.

Genitalia: male: lateral apodeme laterally extended and distally broadened; anterior apodeme acute; a pair of acute dorsal apodemes; lateral rod very broad ventrally and with a blunt, anterior projection; ejaculatory canal atrium large and cup-shaped. Female: with 1 pair of lateral cribriform plates and 2 pairs of median cribriform plates.

Dimensions ( $\mathrm{mm}$ ): Male: holotype (WAM T85198) followed by five other males selected from WAM T64692 (where applicable): Body length 3.92 (3.76-4.35). Pedipalps: trochanter $0.580 / 0.417$, femur $1.416 / 0.329$ (1.293-1.480/0.315-0.358), patella 1.095/0.359 (0.986$1.148 / 0.351-0.402$ ), chela (with pedicel) 2.094/0.488 (1.950-2.167/0.470-0.550), chela (without pedicel) 1.925 (1.829-2.078), hand length 1.046 (0.978-1.127), movable finger length 0.916 (0.915-1.037). Chelicera 0.365/0.166, movable finger length 0.228. Carapace 1.119/1.272 (1.1451.224/1.217-1.389); eye diameter, anterior 0.088 , posterior 0.112. Leg I: femur $0.389 / 0.187$, patella $0.383 / 0.211$, tibia 0.443/0.138, metatarsus 0.214/0.106, tarsus $0.182 / 0.097$. Leg IV: femur + patella $1.046 / 0.266$, tibia $0.658 / 0.143$, metatarsus 0.264/0.120, tarsus 0.234/0.110.

Female: paratype (WAM T64691) followed by five other females selected from WAM T85202 (where applicable): Body length 5.10 (4.80-5.19). Pedipalps: trochanter $0.677 / 0.487$, femur $1.596 / 0.365$ (1.566-1.677/0.360-0.403), patella 1.243/0.418 (1.215$1.310 / 0.401-0.444$ ), chela (with pedicel) 2.292/0.569 (2.300-2.466/0.571-0.606), chela (without pedicel) 2.180 (2.226-2.379), hand length 1.177 (1.202-1.276), movable finger length 1.090 (1.081-1.124). Chelicera $0.429 / 0.222$, movable finger length 0.286 . Carapace $1.369 / 1.476$ (1.272-1.378/1.471-1.632); eye diameter, anterior 0.094 , posterior 0.107 . Leg I: femur 0.311/0.216, patella $0.449 / 0.250$, tibia $0.508 / 0.155$, metatarsus $0.256 / 0.115$, tarsus $0.205 / 0.094$. Leg IV: femur + patella $1.182 / 0.293$, tibia $0.775 / 0.160$, metatarsus $0.301 / 0.140$, tarsus $0.229 / 0.119$.

\section{Tritonymph}

Colour slightly paler than in adults, mostly deep yellow-brown.

Chelicera: with 5 setae on hand and 1 on movable finger; galea unbranched.

Pedipalp: trochanter 1.40 , femur 4.06, patella 2.67, chela (with pedicel) 3.92, chela (without pedicel) 3.69, hand (without pedicel) 2.01 times longer than broad, and movable finger 0.89 times longer than hand (without pedicel). Fixed chelal finger with 6 trichobothria, movable chelal finger with 1 trichobothrium (Figure 10): $e b$, ist and $i b$ situated basally; est situated medially; et distally; it subdistally; $t$ subdistally.

Carapace: 0.92 times longer than broad; with 2 pairs of rounded corneate eyes; with 2 setae near anterior margin and 2 near posterior margin; without furrows.

Legs: much as in adults, except metatarsi and tarsi fused.

Abdomen: tergal chaetotaxy: 4: 4: 6: 6: 6: 6: 6: 6: 6: 6: 6: 2. Sternal chaetotaxy: 0: (0) 2 (0): (0) 4 (0): 6: 6: 6: 6: 6: 6: $2: 2$.

Dimensions (mm): paratype (WAM T85199): body length 3.82. Pedipalps: trochanter $0.498 / 0.355$, femur $1.146 / 0.282$, patella $0.848 / 0.318$, chela (with pedicel) $1.684 / 0.430$, chela (without pedicel) 1.585, hand length 0.863 , movable finger length 0.767. Carapace 0.977/1.059.

\section{Deutonymph}

Colour paler than in adults, mostly yellow-brown.

Chelicera: with 5 setae on hand and 1 on movable finger; galea unbranched.

Pedipalp: trochanter 1.38 , femur 3.40 , patella 2.44, chela (with pedicel) 3.46 , chela (without pedicel) 3.21 , hand (without pedicel) 1.75 times longer than broad, and movable finger 0.90 times longer than hand (without pedicel). Fixed chelal finger with 5 trichobothria, movable chelal finger with 1 trichobothrium (Figure 11): $e b$, ist situated basally; est situated medially; et distally; it subdistally; $t$ submedially.

Carapace: 0.93 times longer than broad; with 2 pairs of rounded corneate eyes; with 2 setae near anterior margin and 3 near posterior margin; without furrows.

Legs: much as in adults, except metatarsi and tarsi completely fused.

Abdomen: tergal chaetotaxy: 3: 4: 4: 4: 4: 5: 6: 6: 6: 6: 2: 2 . Sternal chaetotaxy: 0: (0) 2 (0): (0) 3 (0): 3: 6: 6: 6: 6: 6: 4: 2 .

Dimensions ( $\mathrm{mm}$ ): paratype (WAM T85201): body length 2.70. Pedipalps: trochanter $0.420 / 0.305$, femur $0.929 / 0.273$, patella $0.743 / 0.305$, chela (with pedicel) $1.472 / 0.426$, chela (without pedicel) 1.367, hand length 0.747 , movable finger length 0.672. Carapace $0.908 / 0.980$.

\section{Protonymph}

Colour paler than in adults, mostly pale yellow-brown.

Chelicera: with 4 setae on hand and 0 on movable finger; galea unbranched.

Pedipalp: trochanter 1.48, femur 2.99, patella 2.18, chela (with pedicel) 3.24, chela (without pedicel) 2.93, hand (without pedicel) 1.41 times longer than broad, and movable finger 1.09 times longer than hand (without pedicel). Fixed chelal finger with 3 trichobothria, movable chelal finger with 1 trichobothrium (Figure 12): $e b$ and ist situated basally; et distally; $t$ submedially.

Carapace: 0.85 times longer than broad; with 2 pairs of rounded corneate eyes; with 2 setae near anterior margin and 2 near posterior margin; without furrows.

Legs: much as in adults, except metatarsi and tarsi completely fused.

Abdomen: tergal chaetotaxy: 2: 2: 2: 4: 4: 4: 4: 4: 4: 4: 4: 2. Sternal chaetotaxy: 0: (0) 2 (0): (0) 2 (0): 2: 2: 2: 2 : 2: $2: 2: 2$. 
Dimensions ( $\mathrm{mm}$ ): paratype (WAM T80666): body length 2.62. Pedipalps: trochanter $0.355 / 0.240$, femur $0.663 / 0.222$, patella $0.552 / 0.253$, chela (with pedicel) $1.095 / 0.338$, chela (without pedicel) 0.989 , hand length 0.475 , movable finger length 0.516 . Carapace $0.742 / 0.875$.

\section{REMARKS}

Synsphyronus francesae occurs on granite outcrops along the south coast of Western Australia (Figure 3) where they congregate, often in large numbers, under exfoliating granite slabs. Populations of $S$. francesae are well represented in conservation reserves and have been found in Cape Arid National Park, Fitzgerald National Park, Cape Le Grand National Park and Recherche Archipelago Nature Reserve. The easternmost locations are situated at Mt Arid and Poison Creek in the Cape Arid National Park, and Middle Island and Goose Island in the Recherche Archipelago Nature Reserve. The westernmost locations are located $200 \mathrm{~km}$ away in the Fitzgerald National Park, with one specimen collected in the Eyre Range and another on the south slopes of East Mount Barren. The remaining locations are situated within Cape Le Grand National Park and Duke of Orleans Bay; the latter location is the only one thus far outside of a national park or nature reserve.

Four females were collected with brood-sacs attached to their gonopores: two females (WAM T78833) collected on 17 November 2006 each had a brood-sac with seven small embryos, a female (WAM T56028) collected on 29 December 1998 had a brood-sac with six small embryos, and a female (WAM T64691) collected on 15 January 2004 had a brood-sac with nine large embryos. Thus, it appears that the females brood their embryos during summer.

\section{ETYMOLOGY}

This species is named for my daughter, Frances Harvey, who assisted in the collection of the type specimens.

\section{Synsphyronus ellenae sp. nov.}

Figures 2, 3, 13-21

\section{MATERIAL EXAMINED}

\section{Holotype}

Australia: Western Australia: ${ }^{\lambda}$, Kokerbin Nature Reserve, Kokerbin Rock, 31 53'24"S, 117²2'20"E, 12 November 2002, under granite rocks, M.S. Harvey, M.E. Blosfelds, F. Harvey and E. Harvey (WAM T54167).

\section{Paratypes}

Australia: Western Australia: 5 $\curvearrowright, 5$ (2 with broodsacs), 2 tritonymphs, 1 deutonymph, collected with holotype (WAM T54162, T54168-T54174).

\section{Other material}

Australia: Western Australia: 2 ठ, 3 q, 3 tritonymphs, 2 deutonymphs, Mt Caroline Nature Reserve, 31 ${ }^{\circ} 47^{\prime} 36^{\prime \prime S}, 117^{\circ} 38^{\prime} 34^{\prime \prime E}$, 7 July 2004, under granite rocks at top, M.S. Harvey, J.M. Waldock and R. Engel (WAM T64676, T64677).

\section{DIAGNOSIS}

Adults of Synsphyronus ellenae differ from all other species of the genus by the possession of only six trichobothria on the fixed chelal finger and two on the movable chelal finger (Figure 18), although rarely five or seven trichobothria were recorded on the fixed finger. Other salient features include the separate metatarsi and tarsi (Figures 13, 14), the lateral margins of anterior eyes with cuticle extending over cornea (Figure 16), and chela (with pedicel) length of 1.73-1.84 (ठ), 1.95-2.14 () $\mathrm{mm}$.

\section{DESCRIPTION}

\section{Adults}

Colour of sclerotized portions generally dark redbrown (Figure 2). Waxy epicuticle. Setae generally aligned perpendicularly to body, each seta quadricarinate. Most cuticular surfaces roughened, but not granulate.

Chelicera: with 5 setae on hand and 1 subdistal seta on movable finger, all setae acuminate; setae $s b s$ and bs shorter than others; with 2 dorsal lyrifissures and 1 ventral lyrifissure; galea of $\delta$ and $q$ unbranched; rallum of 3 blades, the most distal blade with several serrations on leading edge, other blades smooth; serrula exterior with $21(\hat{0},+$ ) blades; lamina exterior present.

Pedipalp (Figure 17): trochanter 1.46 (ð), 1.48 (), femur 3.80-4.48 (ठ), 3.84-4.13 ()), patella 2.79-2.99 (§), 2.86-2.95 (ㅇ), chela (with pedicel) 3.68-4.11 (ð), 3.48-3.77 (9), chela (without pedicel) 3.46-3.81 (ठ), 3.29-3.55 (9), hand (without pedicel) 1.84-2.02 (ठ)), 1.77-1.89 () times longer than broad, movable finger 0.90-0.98 (ठ), 0.79-0.92 () times longer than hand. Fixed chelal finger with 6 (Figure 19), or rarely 5 (Figure 18) or 7 , trichobothria, movable chelal finger with 2 trichobothria (Figures 18, 19), usually with $e s b$, isb, st and $b$ absent: $e b$ situated basally, est submedially, et subdistally, $i b$ and ist basally in diagonal row, and it subdistally, slightly posterior to et; $s b$ situated basally and $t$ situated subdistally; in cases where 5 trichobothria are present on fixed finger, it is absent, and where 7 trichobothria are present, esb is present; patch of microsetae present on external margin of fixed chelal finger near et. Venom apparatus present in both chelal fingers, venom ducts long, terminating in nodus ramosus basal to et in fixed finger and basal to $t$ in movable finger. Chelal teeth retrorse and acute distally, becoming rounded basally; fixed finger with $51(\lesssim), 60$ () teeth; movable finger with $42\left({ }^{\Uparrow}\right), 53(+)$ teeth; accessory teeth absent.

Carapace (Figure 15): 0.74-0.92 (ð), 0.83-0.90 (ㅇ) times longer than broad; anterior margin of carapace slightly indented medially; subtriangular; with 2 pairs of corneate eyes situated about one-third carapace length from anterior margin, lateral margins of anterior eyes with cuticle extending over cornea (Figure 16); with 

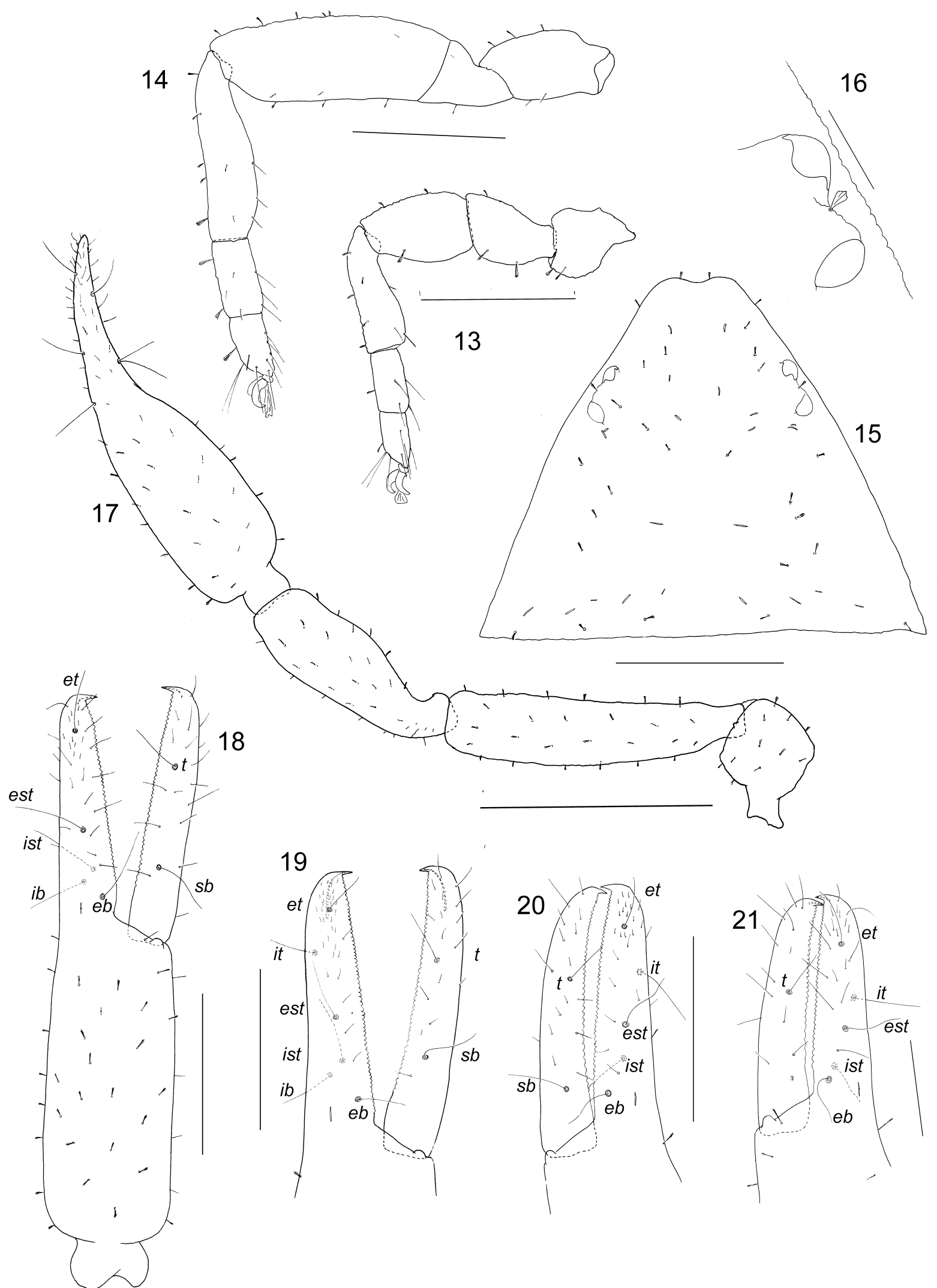

FIGURES 13-21 Synsphyronus ellenae sp. nov., holotype male (WAM T54167), unless stated otherwise: 13, left leg I; 14, left leg IV; 15, carapace; 16, right eye group; 17, left pedipalp, dorsal view; 18, right chela, lateral view; 19, right chelal fingers, lateral view, paratype female (WAM T54169); 20, left chelal fingers, lateral view, paratype tritonymph (WAM T54172); 21, left chelal fingers, lateral view, paratype deutonymph (WAM T54174). Scale lines $=1.0 \mathrm{~mm}$ (Figure 17), $0.5 \mathrm{~mm}$ (Figures 13-15, 18-20), 0.2 $\mathrm{mm}$ (Figure 21), $0.1 \mathrm{~mm}$ (Figure 16). 
c. 21 setae, including $2(\hat{\sigma},+)$ near anterior margin and $5\left({ }^{\Uparrow}\right), 6(+)$ near posterior margin; with numerous lyrifissures; without furrows.

Coxal region: manducatory process rounded, with 3 apical acuminate setae; medial maxillary lyrifissure situated submedially; chaetotaxy of coxae I-IV: 今, 4: 5: 5: 6 ;, , 4: 4: 5: 8 .

Legs (Figures 13, 14): junction between femora and patellae I and II slightly oblique to long axis; junction between femora and patellae III and IV strongly angulate; femora III and IV much smaller than patellae III and IV; femur + patella of leg IV $3.74\left({ }^{\Uparrow}\right), 4.06(+)$ times longer than broad; metatarsi and tarsi not fused and without tactile seta; subterminal tarsal setae arcuate and acute; arolium much longer than claws, not divided.

Abdomen: tergites II-X completely divided by median suture line (Figure 2); sternites V-XI (ð), IX-XI (ํ) with medial suture line, sometimes incompletely divided. Tergal chaetotaxy: ô 8: 7: 9: 10: 10: 11: 9: 11: 10: 10: 4: 2; +, 9: 10: 11: 12: 14: 15: 13: 13: 12: 10: 4: 2; uniseriate; all setae quadricarinate. Sternal chaetotaxy: $\hat{0}, 9[3+3]$ : (0) 4 (0): (0) 6 (0): 5: 5: 7: 8: 10: 9: 4: 2; ㅇ 10: (0) 10 (0): (0) 8 (0): 10: 13: 12: 11: 12: 12: 12: 2; uniseriate; all setae quadricarinate except for setae on sternites II-IV and medial setae on sternites V-IX, which are acuminate. Spiracles without helix. Anal plates (tergite XII and sternite XII) situated within sternite XI, surrounded by slightly raised rim. Pleural membrane wrinkled-plicate; without any setae.

Genitalia: male: lateral apodeme laterally extended and distally broadened; anterior apodeme acute; a pair of acute dorsal apodemes; lateral rod very broad ventrally and with a blunt, anterior projection; ejaculatory canal atrium large and cup-shaped. Female: with one pair of lateral cribriform plates and 2 pairs of median cribriform plates.

Dimensions (mm): Male: holotype (WAM T54167) followed by four other males (WAM T54168) (where applicable): Body length 4.03 (3.63-3.81). Pedipalps: trochanter $0.558 / 0.381$, femur $1.264 / 0.282$ (1.156$1.282 / 0.297-0.337)$, patella $0.942 / 0.319(0.931-$ $1.026 / 0.3290 .360$ ), chela (with pedicel) $1.816 / 0.442$ (1.731-1.844/0.456-0.501), chela (without pedicel) 1.687 (1.646-1.736), hand length 0.866 (0.860-0.920), movable finger length $0.846(0.816-0.845)$. Chelicera $0.348 / 0.166$, movable finger length 0.224 . Carapace $1.051 / 1.294(0.960 / 1.111 / 1.049-1.237)$; eye diameter, anterior 0.059 , posterior 0.080 . Leg I: femur $0.257 / 0.182$, patella $0.348 / 0.209$, tibia $0.412 / 0.136$, metatarsus $0.206 / 0.099$, tarsus $0.178 / 0.088$. Leg IV: femur + patella $0.954 / 0.255$, tibia $0.596 / 0.152$, metatarsus $0.257 / 0.120$, tarsus $0.207 / 0.115$.

Female: paratype (WAM T54169) followed by four other female paratypes (WAM T54170, T54171) (where applicable): Body length 5.38 (4.75-5.23). Pedipalps: trochanter $0.638 / 0.430$, femur $1.480 / 0.358$ (1.348-1.477/0.350-0.382), patella 1.140/0.392 (1.092$1.166 / 0.382-0.421$ ), chela (with pedicel) $2.125 / 0.563$
(1.947-2.141/0.560-0.606), chela (without pedicel) 1.996 (1.866-2.045), hand length 1.065 (0.997-1.077), movable finger length 0.970 (0.850-0.949). Chelicera $0.413 / 0.212$, movable finger length 0.297 . Carapace 1.224/1.482 (1.180-1.284/1.327-1.434); eye diameter, anterior 0.053, posterior 0.074. Leg I: femur 0.294/0.208, patella $0.382 / 0.236$, tibia $0.430 / 0.150$, metatarsus $0.220 / 0.115$, tarsus $0.180 / 0.100$. Leg IV: femur + patella $1.150 / 0.283$, tibia $0.691 / 0.165$, metatarsus $0.260 / 0.166$, tarsus $0.245 / 0.125$.

\section{Tritonymph}

Colour slightly paler than in adults, mostly deep yellow-brown.

Chelicera: with 5 setae on hand and 1 on movable finger; galea unbranched.

Pedipalp: trochanter 1.41, femur 3.75, patella 2.60, chela (with pedicel) 3.84, chela (without pedicel) 3.68, hand (without pedicel) 1.78 times longer than broad, and movable finger 0.88 times longer than hand (without pedicel). Fixed chelal finger with 5 trichobothria, movable chelal finger with 2 trichobothria (Figure 20): $e b$ and $i b$ situated basally; est situated medially; et distally; it subdistally; $s b$ subbasally and $t$ medially.

Carapace: 0.92 times longer than broad; with 2 pairs of corneate eyes, lateral margins of anterior eyes with cuticle extending over cornea; with 2 setae near anterior margin and 4 near posterior margin; without furrows.

Legs: much as in adults except metatarsi and tarsi fused, with faint suture line visible on some legs.

Abdomen: tergal chaetotaxy: 6: 6: 6: 8: 10: 10: 11: 8: 10: 8: 4: 2. Sternal chaetotaxy: 1: (0) 6 (0): (0) 6 (0): 6: 5: 8: 8: 10: 10:2: 2 .

Dimensions ( $\mathrm{mm}$ ): paratype (WAM T54172): body length 3.95. Pedipalps: trochanter $0.488 / 0.346$, femur $1.066 / 0.284$, patella $0.835 / 0.321$, chela (with pedicel) $1.648 / 0.429$, chela (without pedicel) 1.578 , hand length 0.875 , movable finger length 0.774. Carapace $1.006 / 1.091$.

\section{Deutonymph}

Colour much paler than in adults, mostly orange-brown.

Chelicera: with 5 setae on hand and 1 on movable finger; galea unbranched.

Pedipalp: trochanter 1.52, femur 3.37, patella 2.33, chela (with pedicel) 3.59, chela (without pedicel) 3.31, hand (without pedicel) 1.66 times longer than broad, and movable finger 0.96 times longer than hand (without pedicel). Fixed chelal finger with 5 trichobothria, movable chelal finger with 1 trichobothrium (Figure 21): $e b$ and $i b$ situated basally; est situated medially; et distally; it subdistally; $t$ medially.

Carapace: 0.91 times longer than broad; with 2 pairs of corneate eyes, lateral margins of anterior eyes with cuticle extending over cornea; with 2 setae near anterior margin and 4 near posterior margin; without furrows.

Legs: much as in adults except metatarsi and tarsi fused. 
Abdomen: tergal chaetotaxy: 4: 4: 6: 6: 6: 6: 6: 6: 6: 6: 4: 2. Sternal chaetotaxy: 0: (0) 2 (0): (0) 2 (0): 2: 4: 4: 6 : 8: 8: $4: 2$.

Dimensions ( $\mathrm{mm}$ ): paratype (WAM T54174): body length 2.86. Pedipalps: trochanter 0.384/0.253, femur $0.755 / 0.224$, patella $0.600 / 0.257$, chela (with pedicel) $1.188 / 0.331$, chela (without pedicel) 1.096, hand length 0.575 , movable finger length 0.551 . Carapace $0.726 / 0.800$.

\section{REMARKS}

Synsphyronus ellenae has only been found at Kokerbin Rock and Mt Caroline in the central wheatbelt of Western Australia (Figure 3). The specimens were found under pieces of exfoliating granite. Two females (WAM T54169 and T54170) collected at Kokerbin Rock in November 2002 were carrying brood-sacs with 10 and 9 embryos, respectively.

\section{ETYMOLOGY}

This species is named for my daughter, Ellen Harvey, who assisted in the collection of the type specimens.

\section{DISCUSSION}

\section{TRICHOBOTHRIAL REDUCTION IN GARYPIDAE}

Pseudoscorpions of the family Garypidae can be divided into two groups, one ('garypines' sensu Harvey 1996b) comprising the halophilic genus Garypus L. Koch 1873, and the other ('synsphyronines' sensu Harvey 1996b) with the remaining genera: Ammogarypus Beier, 1962, Anagarypus Chamberlin, 1930, Elattogarypus Beier, 1964, Eremogarypus Beier, 1955, Meiogarypus Beier, 1955, Neogarypus Vachon, 1937, Paragarypus Vachon, 1937, Synsphyronus and Thaumastogarypus Beier, 1947. These two groups are reciprocally monophyletic, although the relationships within each group have yet to be fully resolved (Harvey 1996b; M.S. Harvey, unpublished data).

There have been no reported reductions of adult trichobothrial number in Garypus and all possess the plesiomorphic condition of eight trichobothria on the fixed chelal finger and four trichobothria on the movable chelal finger (8/4). In the second group (the 'synsphyronines'), all three species of Ammogarypus have 8/2 (Beier 1962, 1964, 1973), the three species of Anagarypus have either $7 / 2$ or $7 / 1$ (Muchmore 1982), the three species of Elattogarypus have 5/1 (Beier 1964; Mahnert 1984, 2007), the four species of Eremogarypus have either $8 / 3,8 / 2$ or $5 / 1$ (Beier $1955,1962,1973$ ), the sole species of Meiogarypus has 6/2 (Beier 1955), the sole species of Neogarypus has 8/4 (Vachon 1937a), the sole species of Paragarypus has 8/3 (Vachon 1937b), the 28 species of Synsphyronus have 8/3, 8/2, 8/1, 7/2 or $7 / 1$ (Harvey 1987), and the majority of the eight species of Thaumastogarypus have 8/4 (e.g. Beier 1947, 1955, 1958, 1964) with the exception of T. mancus Mahnert, 1982 which has 7/3 (Mahnert 1982). The labile nature of adult trichobothrial numbers between synsphyronine species is obviously well-entrenched, and the addition of new species of Synsphyronus with patterns of $7 / 1$ ( $S$. francesae) and $6 / 2$ (S. ellenae) confirms and, in the case of $S$. ellenae, extends its range in this diverse genus. Although the $6 / 2$ trichobothrial pattern of $S$. ellenae is the lowest thus far found in the genus Synsphyronus, lower numbers have been found in Elattogarypus cruciatus Beier, 1964 from South Africa, E. somalicus Mahnert, 1984 from Somalia, E. cicatrosus Mahnert, 2007 from the Yemeni island of Socotra, and Eremogarypus eximius Beier, 1973 from Namibia, each with 5/1 pattern (Beier 1973; Mahnert 1984, 2007).

\section{CONSERVATION OF GRANITE DWELLING SPECIES OF SYNSPHYRONUS}

Granite outcrops rise above the landscape over much of southern Western Australia (Withers 2001). The granites of the Yilgarn craton were formed 2,600 to 2,700 million years ago, whilst other granites range from 2,000 to about 500-800 million years old (Withers 2001). Pseudoscorpions of the genus Synsphyronus are common inhabitants of rock outcrops within Australia, occurring under a variety of rock types including granite, sandstones, schists, dolerites and limestone (Harvey 1987; M.S. Harvey, unpublished data). They are commonly encountered on granite outcrops in southern Western Australia, often in large aggregations, making them a conspicuous element of the lithocolous fauna of the region. Whilst some species prefer to accumulate under rocks which are embedded directly in soil, or with soil that has accumulated between two pieces of rock, many species prefer a 'rock-on-rock' position, with very little accumulated soil or plant debris (M.S. Harvey, personal observations).

The systematic status of the granite-dwelling species of Synsphyronus in southwestern Australia is imperfectly known. Synsphyronus elegans Beier, 1954 was described from Yorkrakine Rock, near Tammin in the central wheatbelt (Beier 1954; Harvey 1987) and has since been recorded from a few other nearby granite outcrops (R. Engel and M.S. Harvey, unpublished data). Synsphyronus leo Harvey, 1987 was described from specimens collected under granite slabs on Lion Island, situated in the Recherche Archipelago (Harvey 1987). The widespread S. hansenii (With, 1908), which is found in Tasmania, Victoria and southern Western Australia (Harvey 1987), occurs in a variety of habitats, including under bark of eucalypt and Allocasuarina trees, in moss and grass tussocks, under rocks, in houses and even in the pelage of a bandicoot (Perameles sp.) (Beier 1954; Harvey 1987). In southern Western Australia S. hansenii occurs under the bark of eucalypt trees in the high rainfall zone near the south coast (Harvey 1987; M.S. Harvey, unpublished data). At Mt Chudalup - a large monolithic granite mondanock situated in the D'Entrecasteaux National Park - specimens of $S$. hansenii occur under slabs of granite, usually without any accumulated soil (Harvey 
1987; M.S. Harvey, unpublished data). Specimens of Synsphyronus mimulus Chamberlin, 1943 have also been found under exfoliating granite pieces, but almost always in situations where they are in contact with soil. Indeed they are most easily found under rocks which are partially embedded in soil (M.S. Harvey, unpublished data). They demonstrate a wider habitat tolerance than most other species of Synsphyronus and also occur in leaf litter and have been found across much of southern Australia (Harvey 1987). Synsphyronus francesae and $S$. ellenae appear to be true lithophiles and have never been reported from habitats other than granite rocks. In all cases, they have been found in 'rock-on-rock' habitats, never under rocks that are embedded in soil. All of these three species have limited distributions and meet the criteria for short-range endemic species defined by Harvey (2002).

Most populations of the new lithocolous species are located within conservation reserves, but they may be under threat through the removal of pieces of exfoliated granite (Main 1998b; Twidale 2001). Granite pieces are sometimes removed for garden or house decorations, and granite outcrops are frequently visited by sightseers, some of whom cannot resist the temptation to throw smaller pieces of granite as far as they can from the higher outcrops. At other sites where vehicular access is possible due to the low relief of the granite rock, the increasing use of off-road four-wheel drive vehicles is crushing exfoliated granite pieces and destroying any remaining habitat for the lithocolous fauna (M.S. Harvey, personal observations). Signs installed for the public by the Department of Environment and Conservation at Yorkrakine Rock Nature Reserve in Western Australia highlight the plight of the fauna of the granite dome and encourage visitors to minimise their impact when visiting the region.

\section{ACKNOWLEDGEMENTS}

I am very grateful to my family for their assistance in the collection of these two new species. I also admire their patience - they know what I mean. Other specimens were provided by Roberta Engel, Frances Leng, Alan Longbottom, Melinda Moir and Julianne Waldock. The opportunity to collect specimens on Middle Island was provided by Sarah Comer and her colleagues in the Department of Environment and Conservation. Some specimens were obtained by Melinda Moir and Frances Leng during surveys documenting the short-range endemic fauna of southwestern Australia, funded by the Southcoast Natural Resource Management Inc., to whom I am grateful for their support. I am grateful to the editor, Paul Doughty, and two anonymous referees for the constructive comments on a draft of the manuscript.

\section{REFERENCES}

Bayly, I.A.E. (1999). Rock of ages: human use and natural history of granite outcrops. Tuart House: Nedlands,
Australia.

Beier, M. (1947). Zur Kenntnis der Pseudoscorpionidenfauna des südlichen Afrika, insbesondere der südwest- und südafrikanischen Trockengebiete. Eos, Madrid 23: 285-339.

Beier, M. (1954). Report from Prof. T. Gislén's expedition to Australia in 1951-1952. 7. Pseudoscorpionidea. Acta Universitatis Lundensis, nova series (2) 50: 1-26.

Beier, M. (1955). Pseudoscorpionidea (pp. 263-328). In: Hanstrom, B., Brinck, P. and Rudebeck, G. (eds), South African animal life. Results of the Lund Expedition in 19501951, vol. 1. Almquist and Wiksell: Stockholm.

Beier, M. (1958). The Pseudoscorpionidea (false-scorpions) of Natal and Zululand. Annals of the Natal Museum 14: $155-187$.

Beier, M. (1962). Pseudoscorpioniden aus der Namib-Wüste. Annals of the Transvaal Museum 24: 223-230.

Beier, M. (1964). Weiteres zur Kenntnis der Pseudoscorpioniden-Fauna des südlichen Afrika. Annals of the Natal Museum 16: 30-90.

Beier, M. (1973). Weiteres zur Kenntnis der Pseudoscorpioniden Südwestafrikas. Cimbebasia, A 2: 97-101.

Chamberlin, J.C. (1930). A synoptic classification of the false scorpions or chela-spinners, with a report on a cosmopolitan collection of the same. Part II. The Diplosphyronida (Arachnida-Chelonethida). Annals and Magazine of Natural History (10) 5: 1-48, 585-620.

Chamberlin, J.C. (1931). The arachnid order Chelonethida. Stanford University Publications, Biological Sciences 7(1): $1-284$.

Chamberlin, J.C. (1943). The taxonomy of the false scorpion genus Synsphyronus with remarks of the sporadic loss of stability in generally constant morphological characters (Arachnida: Chelonethida). Annals of the Entomological Society of America 36: 486-500.

Harvey, M.S. (1987). A revision of the genus Synsphyronus Chamberlin (Garypidae: Pseudoscorpionida: Arachnida). Australian Journal of Zoology, Supplementary Series 126: 1-99.

Harvey, M.S. (1992). The phylogeny and classification of the Pseudoscorpionida (Chelicerata: Arachnida). Invertebrate Taxonomy 6: 1373-1435.

Harvey, M.S. (1996a). The biogeography of Gondwanan pseudoscorpions (Arachnida). Revue Suisse de Zoologie, hors série 1: 255-264.

Harvey, M.S. (1996b). Small arachnids and their value in Gondwanan biogeographic studies (pp. 155-162). In: Hopper, S.D., Chappill, J.A., Harvey, M.S. and George, A.S. (eds), Gondwanan heritage: past and future of the Western Australian biota. Surrey Beatty \& Sons: Chipping Norton, Australia.

Harvey, M.S. (2002). Short-range endemism in the Australian fauna: some examples from non-marine environments. Invertebrate Systematics 16: 555-570.

Judson, M.L.I. (2007). A new and endangered species of the pseudoscorpion genus Lagynochthonius from a cave in Vietnam, with notes on chelal morphology and the composition of the Tyrannochthoniini (Arachnida, Chelonethi, Chthoniidae). Zootaxa 1627: 53-68.

Mahnert, V. (1982). Die Pseudoskorpione (Arachnida) Kenyas, IV. Garypidae. Annales Historico-Naturales Musei Nationalis Hungarici 74: 307-329.

Mahnert, V. (1984). Forschungen an der Somalilandküste. Am Strand und auf den Dünen bei Sar Uanle. 36. 
Pseudoscorpiones (Arachnida). Monitore Zoologico Italiano, n.s., Supplemento 19: 43-66.

Mahnert, V. (2007). Pseudoscorpions (Arachnida: Pseudoscorpiones) of the Socotra Archipelago, Yemen. Fauna of Arabia 23: 271-307.

Main, B.Y. (2001). Habitat template for invertebrates on granite outcrops. Journal of the Royal Society of Western Australia 83: 139-147.

Main, B.Y. (1998a). Granite outcrops: a collective ecosystem. Journal of the Royal Society of Western Australia 80: $113-122$.

Main, A.R. (1998b). Management of granite rocks. Journal of the Royal Society of Western Australia 80: 185-188.

Morris, J.C.H. (1948). The taxonomic position of Idiogarypus hansenii (With). Papers and Proceedings of the Royal Society of Tasmania 1947: 37-41.
Muchmore, W.B. (1982). The genus Anagarypus (Pseudoscorpionida: Garypidae). Pacific Insects 24: 159-163.

Twidale, C.R. (2001). Granite outcrops: their utilisation and conservation. Journal of the Royal Society of Western Australia 83: 115-122.

Vachon, M. (1937a). Pseudoscorpions nouveaux des collections du Muséum National d'Histoire Naturelle de Paris (Première note). Bulletin du Muséum National d'Histoire Naturelle, Paris (2) 9: 129-133.

Vachon, M. (1937b). Pseudoscorpions nouveaux des collections du Muséum National d'Histoire Naturelle de Paris. (3 ${ }^{\mathrm{e}}$ note). Bulletin de la Société Entomologique de France 42: 188-190.

Withers, P.C. (2001). Overview of granite outcrops in Western Australia. Journal of the Royal Society of Western Australia 83: 103-108.

Withers, P.C. and Edward, D.H. (1998). Terrestrial fauna of granite outcrops in Western Australia. Journal of the Royal Society of Western Australia 80: 159-166.

MANUSCRIPT RECEIVED 5 NOVEMBER 2009; ACCEPTED 24 NOVEMBER 2009. 